\title{
Determinants of farmers' perception about climate change in Khyber Pakhtunkhwa-Pakistan
}

\author{
Aftab Khan ${ }^{1 *}$, Sanaullah ${ }^{2}$, Shahid $\mathrm{Ali}^{3}$, Syed Attaullah $\mathrm{Shah}^{4}$ and Sufyan \\ Ullah Khan ${ }^{5}$ \\ 1. Department of Agricultural \& Applied Economics, The University of Agriculture, Peshawar-Pakistan \\ 2. Department of Agricultural Extension Education \& Communication, The University of Agriculture, Peshawar- \\ Pakistan \\ 3. Department of Agricultural \& Applied Economics, The University of Agriculture, Peshawar-Pakistan \\ 4. Department of Agricultural \& Applied Economics, The University of Agriculture, Peshawar-Pakistan \\ 5. College of Economics and Management, Northwest A\&F University, Yangling, 712100, Shaanxi-China \\ *Corresponding author's email:_aftabeconomist@aup.edu.pk \\ Citation \\ Aftab Khan, Sanaullah, Shahid Ali, Syed Attaullah Shah and Sufyan Ullah Khan. Determinants of farmers' \\ perception about climate change in Khyber Pakhtunkhwa-Pakistan. Pure and Applied Biology. Vol. 8, Issue 4, \\ pp2159-2168. http://dx.doi.org/10.19045/bspab.2019.80161
}

\begin{tabular}{llll}
\hline Received: 13/05/2019 & Revised: 15/07/2019 & Accepted: 18/07/2019 & Online First: 24/07/2019 \\
\hline \hline
\end{tabular}

\section{Abstract}

Climate change is a global environmental threat to almost all economic sectors, especially the agricultural sector and Pakistan is no exception to these threats. In Pakistan, farmers are the primary stakeholders in agriculture and are more at risk due to climatic vulnerability. This study, therefore examined farmers' perception about climate change across four agro-climatic zones of Khyber Pakhtunkhwa-Pakistan. A total of 210 farmers were selected through multistage random sampling technique and interviewed by using a well-designed interview schedule. The study results revealed that maize and wheat were the two main crops cultivated by $99.05 \%$ and $97.14 \%$ respondents, respectively. Among the total targeted respondents, $89.52 \%$ respondents reported an increase in temperature, whereas $79.05 \%$ observed decrease in rainfall in the province. The logistic regression analysis was carried out to assess factors influencing farmers' perceptions of climate change. The analysis revealed that $89.52 \%$ of farmers in Khyber Pakhtunkhwa had a perception that climate was changing. In this respect, age, educations, household size, farming experience and farm income were recorded having statistically significant effect on the probability of the respondents to perceive climate change. It is concluded that mean temperature was increased, while a significant decrease was noted in annual precipitation. Based on the study findings, it is recommended that policy makers should devise policies helping the farmers in coping with changing climate to avoid adverse effects of climatic pattern on overall crop yield. Agricultural extension and meteorological department should work together to forecast weather conditions and transfer the required information and mitigation strategies to the target farming community.

Keywords: Climate change; Logit regression; Khyber Pakhtunkhwa-Pakistan; Perception

\section{Introduction}

United Nation Framework Convention on Climate Change (UNFCC) defined climate change as a long-term change in the earth's climate, specifically a change due to increase in the average atmospheric temperature [1]. 
This change is more apparent during the last five decades. Human livelihood activities lead to the emission of greenhouse gases (GHG). These GHGs mainly consist of Nitrous oxides $\left(\mathrm{NO}_{2}\right)$, Carbon dioxide $\left(\mathrm{CO}_{2}\right)$ and Methane $\left(\mathrm{CH}_{4}\right)$ [2]. Increase in the concentration of these gases during the past 50 years have resulted in global warming [3]. This rise in atmospheric temperature has increased evaporation from water bodies and has indirectly changed the intensities and frequencies of rainfalls in different regions [4]. Climate change is a serious and alarming threat to farmers all over the world who reside in marginalized and distant areas like deserts, dry lands and mountainous places [5]. Climate change and unevenness of weather conditions have threatened the productivity of agriculture in most parts of the world. High atmospheric temperatures affect plants, animals and farmers' health. It increase pests' growth, and causes aridity and land degradation by reducing water supply. Modified precipitation patterns result water scarcity and droughts and creates stress for crops and livestock. Storm, drought and floods, induced by climate change, are potential threats to humans and other living organisms [6].

Pakistan is highly vulnerable to climate variability and extremes. Changing climate is strictly related to poverty reduction and food security which are big challenges for the agricultural sector of the country. Agriculture is the second largest sector in Pakistan that contributes 19.8 percent to GDP and absorbs 42.3 percent of the workforce. Around 62 percent of the country's population resides in rural areas, and is directly or indirectly linked with crops production and livestock farming [7].

Despite the reason that there is abundant food production, the country is still not selfsufficient. In this background, important measures are needed to be taken helping farmers to improve their mitigation regarding impact of changing climate on crop production. It is documented by Task Force Planning Commission (TFPC) on climate change that there is an urgent need to measure the impact of climate change on various sectors of the economy for planning and policy making of Pakistan [8].

Khyber Pakhtunkhwa has different climate conditions and a number of crops require specific suitability for their vegetative reproduction. Farmers belong to different areas has different response to climate change. Types of adaptation in farming communities include switching to alternative crops which are more profitable changing growing traditional method and cultivate early or later a specific crops. Such sort of method is very common and used by majority of the farmers. To educate the farmers is keen responsibility of extension workers who teach them the news method of adaptation to mitigate hazardous of climate change which suffer our farming community. Adaptation is one of the pre-occupations in the field of climate change and disaster risk reduction. As such humanity has been adapting for generations to changing circumstance forced by natural or human beings, though such forced human adjustments were not necessarily called adaptation. What may be new these days is that the frequency and intensity of the risks has increased and that vulnerable communities are faced with increasing pressure to do more. But, what can poor farming communities with no other skills, limited alternatives and connections do? It is essential to know about the opportunities and challenges around adaptation in such poor rural communities. The objective of this research is to investigate determinants of farmers' perception about climate change in Khyber Pakhtunkhwa province of Pakistan.

\section{Synthesis of literature reviewed}

Adaptation is one of the important tools to reduce the impact of climate change. In this 
regard, various researchers used different statistical tools to examine farmer's perception about climate change. [9] Estimated perception of the farmers regarding climate change in Kenya where they carried out logistic regression analysis [10] used logit model regress over socioeconomic attributes estimating variation in two variables; temperature and rainfall from year 1941-2010 in Nigeria. Likewise, [11-13] applied Heckman Probit model to analyze adaptation to climate change in Ethiopia and Southeast Asia. [14] used one-way analysis of variance (ANOVA), Garrett ranking technique and percentage analysis to estimate the famers' perception of climate change in South Africa. Similarly, [15] estimated Multinomial Logit (MNL) mode to indicate the determinants of farmer's decisions towards climate change. Descriptive and logistic regression analysis were performed to identify determinants of climate change by [16] in Northern Ethiopia.

\section{Methods and materials}

\section{Sampling procedure and sample size}

Various regions of the world counties could be vulnerable to the impact of climate change as witnessed by [17]. Due to this reason Khyber Pakhtunkhwa was selected because it has different climatic zones. Different regions of many countries have different effects within borders [18]. Multistage sampling procedure was adopted for the selection of respondents. In stage first, one district was randomly selected out of the four climatic zones A, B, C and D. In second stage, four villages were randomly selected from each selected district. In the final stage, 50 registered farmers were randomly selected from each selected village in each district by using proportional allocation sampling technique $[19,20]$ as follows:

$\mathrm{n}_{\mathrm{i}}=\mathrm{n}\left(\mathrm{N}_{\mathrm{i}} / \mathrm{N}\right)$

Where;

$\mathrm{n}_{\mathrm{i}}=$ Sample size selected from ith village

$\mathrm{n}=$ Total sample size
$\mathrm{N}_{\mathrm{i}}=$ Population of registered farmers in ith village

$\mathrm{N}=$ Population of farmers in all selected villages in each district

\section{Data and data collection}

Primary as well as secondary data was used in this study. Primary data from sampled respondents was collected through a wellstructured interview schedule. Interviews with farmers were conducted either in fields or Hujras (communal place in village) to get representative data. Secondary data for this study was gathered from various government publications/sources.

\section{Analytical framework}

To investigate farmers' perception of climate change, logit regression analysis was applied, where the dependent variable is typically qualitative and binary, having possibility of 1 or 0 . To analyze the estimates of binary models, Ordinary Least Squares (OLS) can also be used. Sometimes, assumptions of OLS regression are violated, including nonnormality of the disturbances, heteroscedasticity problems and doubtful value of $\mathrm{R}^{2}$ as the measure of goodness of fit [21] For instance, given:

$y i=\beta o+\beta i X i+e i$

Where $y \mathrm{i}=1$ if a farmer perceives climate change and $y i=0$ if a farmer does not; $\beta_{0}$ is the intercept; $\beta \mathrm{i}$ are the parameters to be estimated; $X$ is a vector of the all those explanatory variables used in the model, whereas ei is the error term.

Linear regression when the dependent variable is dummy in nature then it is referred as Linear Probability Model (LPM). In regression when dependent variable is binary then linear probability model dose not fulfil the OLS assumptions of regression. Due to which it bursts from its ranges and gives misleading results for the conclusions based on hypothesis established [22]. So, Logit and Probit are the most appropriate models to avoid problems related to LPM [21]. 
Between logit and probit, which model is preferable? In most applications the models are quite similar, the main difference being that the logistic distribution has slightly fatter tails, which can be seen in Figure 1. That is to say, the conditional probability $P i$ approaches zero or one at a slower rate in logit than in probit. Maximum Likelihood
Estimation (MLE) techniques guarantee the likelihoods range destined between 0 and 1 . Probit and logit models use MLE which assess cumulative distribution, hence overcomes the problem related with LPM. In practice many researchers choose the logit model because of its comparative mathematical simplicity [21].

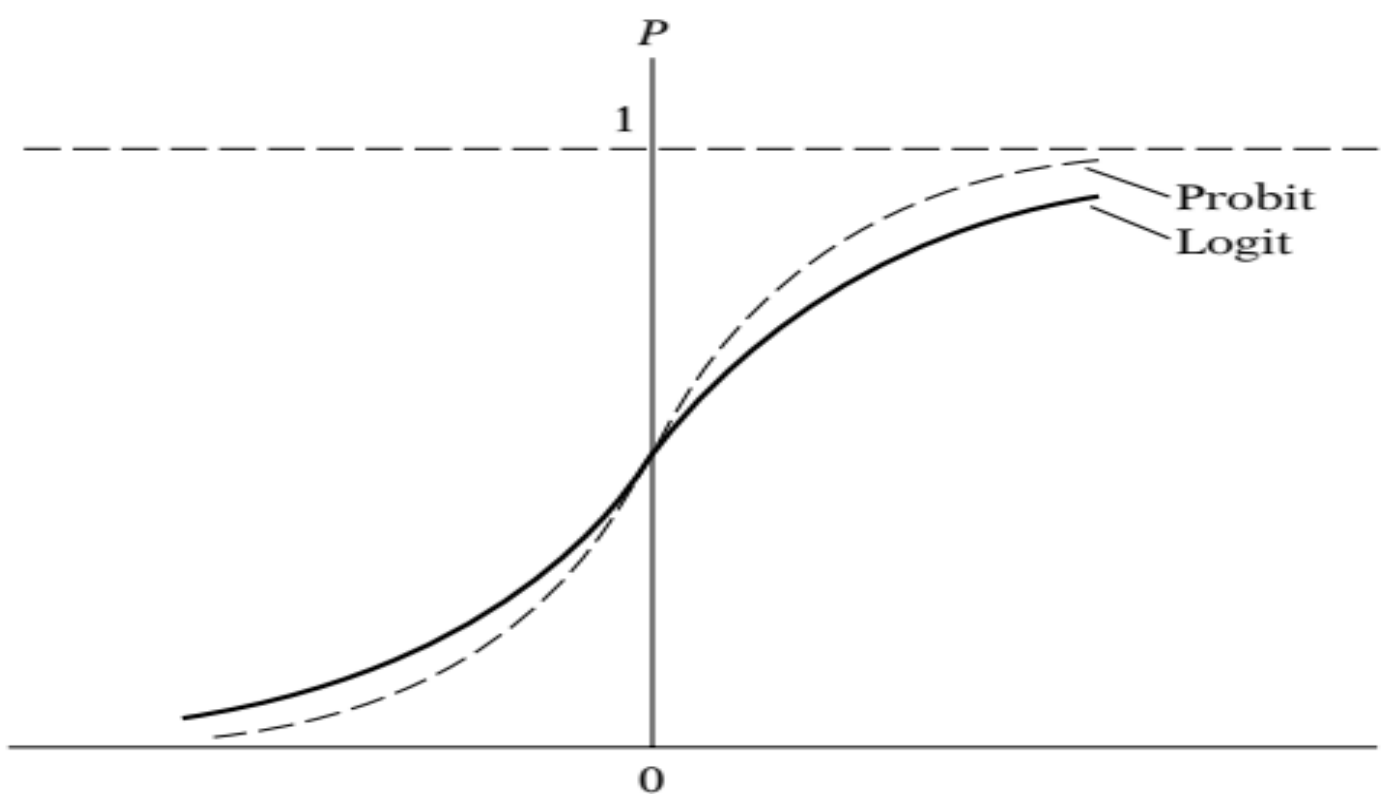

Figure 1. Logit and probit cumulative distributions

The probability and odd ratio are specified as:

$\mathrm{P}_{i}=1 / 1+\mathrm{e}^{(-\mathrm{z})}$

Where;

$\mathrm{Z}_{i=} \log \left(\mathrm{P}_{i} / 1-\mathrm{P}_{i}\right)=\beta_{0}+\beta_{1} \mathrm{X}_{1 \mathrm{i}}+\ldots \beta_{\mathrm{n}} \mathrm{X}_{\mathrm{ni}}+\varepsilon_{\mathrm{i}}$

Where:

$\mathrm{P}_{i}=$ probability of $i$ th farmer to perceive climate change.

$\mathrm{Z}_{i}=$ logit value or the $\log$ of odd ratio $\left(\left(\mathrm{P}_{i} / 1-\right.\right.$ $\mathrm{P}_{i}$ ).

Odd ratio is the possibility of a farmer to perceive change in climate to the possibility that a farmer may not perceive climate change. The marginal effects can also be computed to predict the change in the probability with a unit change in independent variables. The marginal effects are computed as follows: $\frac{\partial P i}{\partial x j i}=\frac{\partial F(z i)}{\partial z i} \cdot \frac{\partial F z i}{\partial x j i} \cdot=f(z i) \cdot \beta j$

\section{Empirical model}

In this study, farmers' perception on climate change is a binary variable determining whether a farmer has perceived climate change or not. Based on literature review as well as economic theory, independent variables were chosen. The independent variables included were; age, education, household size, farm size, farming experience and farm income of respondents. The following binary logit model was used to predict farmers' perception regarding climate change and to identify its various determinants.

$\mathrm{Y}_{i}=\left(\beta \mathrm{X}_{i}\right)$ 
$\mathrm{Y}_{i}=\mathrm{f}$ (Age, Education, Household size, Farm size, Farming experience, Farm income)

Where;

$Y_{i}=$ The perception of $i$ th farmer; $Y_{i}=1$ if farmer perceives that climate is changing, 0 otherwise.

Age $=$ Age of $i$ th farmer in years

Education $=$ Education of $i$ th farmer in schooling years

Household size $=$ Number of family members of $i$ th farmer

Farm size $=$ Farm land of $i$ th farmer in acres

Farming Experience $=$ Farming experience of $i$ th farmer years

Farm income $=$ Income of $i$ th farmer from farming in Rs (Pakistani Rupees)

$\beta=$ Vector of parameter estimates of the explanatory variables

The collected data was analyzed through Statistical Package for Social Sciences (SPSS) and Stata v. 12 softwares to draw final results and conclusions.

\section{Results and discussion}

Socioeconomics characteristics of the respondents

Socioeconomic characteristic is an important determinant of the respondents in order to manipulate the farmers' perception regarding climate change. Demographic attributes identified were age, education, household size, farm size, farming experience and farm income. Age of the farmers play an important role in decision making. The average age reported in Khyber Pakhtunkhwa was 56.32 years. Out of which Peshawar had mean value of 57.77 years, Upper Dir had 55.03 years, Abbottabad had 55.73 years, while district Lakki Marwat was recorded having an average age value of 56.75 years. Education is another important demographic factor which represents literacy rate of farmer community .The mean education value observed was 6.00 years of schooling in Khyber Pakhtunkhwa. District wise data regarding education reveals that respondents in district Peshawar had mean value of 6.71 years of schooling, Upper Dir had mean value of 6.44, and Abbottabad had an average value of 6.07 years of schooling, while district Lakki Marwat had an average value of 4.78 years of schooling. Household Size represents the family strength of the respondents and indicates how they perform their field operations (Table 1).

Table 1. Socioeconomics characteristics of the respondents

\begin{tabular}{|c|c|c|c|c|c|}
\hline $\begin{array}{c}\text { Socioeconomic } \\
\text { Characteristics }\end{array}$ & Central zone & Northern zone & Eastern zone & $\begin{array}{c}\text { Southern } \\
\text { Zone }\end{array}$ & $\begin{array}{c}\text { Khyber } \\
\text { Pakhtunkhwa }\end{array}$ \\
\cline { 2 - 5 } & Peshawar & Upper Dir & Abbottabad & Lakki Marwat & \\
\hline Age & 57.77 & 55.03 & 55.73 & 56.75 & 56.32 \\
\hline Education & 6.71 & 6.44 & 6.07 & 4.78 & 6.00 \\
\hline Household size & 7.54 & 7.05 & 7.32 & 7.16 & 7.27 \\
\hline Male & 4.13 & 3.82 & 3.61 & 4.48 & 4.01 \\
\hline Female & 4.32 & 3.73 & 3.80 & 4.18 & 4.01 \\
\hline Farm size & 5.20 & 4.57 & 4.25 & 11.01 & 6.26 \\
\hline $\begin{array}{c}\text { Farming } \\
\text { experience }\end{array}$ & 42.43 & 40.00 & 40.23 & 41.07 & 40.93 \\
\hline Farm income & 187735.80 & 58211.54 & 83673.08 & 128773.6 & 114598.50 \\
\hline
\end{tabular}

Source: Field survey data, 2017.

The average household size measured was 7.27 in Khyber Pakhtunkhwa, among which district Peshawar had 7.54 members on average, mean value calculated for household size in Upper Dir was 7.05 members, and district Abbottabad had an average of 7.32 
members, while Lakki Marwat area had 7.16 of mean household size. The male and female numbers were approximately same that is 4.01 male and 4.01 female in Khyber Pakhtunkhwa. The gender base data shows that there were 4.13 male and 4.32 female in district Peshawar, district Upper Dir had mean 3.82 male and 3.73 female, average male and female number in Abbottabad was 3.61 and 3.80 respectively, while Lakki Marwat had 4.48 male and 4.18 female population in this research study. Similarly the average farm size of the selected farmers in study area was recorded as 6.26 Acres in Khyber Pakhtunkhwa. Out of which district Peshawar had 5.20 of mean land size, 4.57 acre of average land was observed in Upper Dir, sample respondents in District Abbottabad reported that they have 4.25 acre of land on average, while respondents in Lakki Marwat had 11.01 acre of farm size. Farming experience is an important variable indicating climate change perception of the respondents. The average farming experience of the farmers in Khyber Pakhtunkhwa was 40.93 years. District Peshawar had 42.43 years of farming experience, data concerning farming experience of the respondents in Upper Dir was collected and found that they had mean value of 40.00 years of field experience. District Abbottabad had 40.23 years of farming experience, while Lakki Marwat had 41.07 of farming experience in their fields. Income from Agriculture is also a major factor recognizing family background of the farmers. The mean income obtained from agriculture was Rs. 114598.5 per years. Among which average income of the respondents in district Peshawar was RS. 187735.8, average income of respondents in Upper Dir was Rs. 58211.54, mean income reported in District Abbottabad was Rs. 83673.08, while average income obtained by the respondents in Lakki Marwat was Rs. 128773.6 in this research survey.

\section{Agricultural characteristics of the respondents}

The agricultural characteristics of the respondents play a very important role regarding their perception about change in climate. Wheat and Maize are the two most cultivated crops in Khyber Pakhtunkhwa. Out of the total 210 respondents, 204 respondents cultivated wheat crop which is $97.14 \%$ of the total sample population in the study area. Sugarcane is labor intensive crop and requires a lot of water for irrigation. Therefore in district Peshawar only 22 respondents were found having cultivated sugarcane that is 41.51 percent of the Peshawar sample size. Sugarcane is not cultivated in Abbottabad, Upper Dir., and Lakki Marwat because there was no proper irrigation system and insufficient water which was not enough to fulfill crop requirements. Maize is the queen crop and cultivated everywhere in Khyber Pakhtunkhwa. Out of the total respondents, 208 respondents which is $99.05 \%$ of the sample size cultivated maize crop. There was $100 \%$ cultivation of maize crop in Peshawar, Upper Dir and Abbottabad districts of the study area. Rice is not different from sugarcane, it needs standing water for its growth throughout the season. It was cultivated by only 2 farmers in district Peshawar which was $3.77 \%$ of the whole sample size of Peshawar. Majority of the respondents used to cultivate vegetables full time for self-consumption and for sale in the market to get money. The 44 respondents cultivated vegetables in Khyber Pakhtunkhwa which were approximately $21 \%$ of the total sample size. Irrigation plays an important role in growth and development of all crops. Out of the total 210 respondents, $183(87.14 \%)$ respondents irrigated their land for their crops' cultivation (Table 2). 
Table 2. Agricultural characteristics of the respondents

\begin{tabular}{|c|c|c|c|c|c|c|c|c|c|c|}
\hline \multirow{2}{*}{ Agriculture } & \multicolumn{2}{|c|}{$\begin{array}{c}\text { Central zone } \\
\text { Peshawar }\end{array}$} & \multicolumn{2}{|c|}{$\begin{array}{c}\text { Northern zone } \\
\text { Upper Dir }\end{array}$} & \multicolumn{2}{|c|}{$\begin{array}{c}\text { Eastern zone } \\
\text { Abbottabad }\end{array}$} & \multicolumn{2}{|c|}{$\begin{array}{l}\text { Southern zone } \\
\text { Lakki Marwat } \\
\end{array}$} & \multicolumn{2}{|c|}{$\begin{array}{c}\text { Khyber } \\
\text { Pakhtunkhwa }\end{array}$} \\
\hline & Frea & or & Freg & o & Freg & of & Freg & of & Total & $\%$ \\
\hline Wheat & 50 & 94.34 & 52 & 100 & 49 & 94.23 & 53 & 100 & 204 & 97.14 \\
\hline Sugarcane & 22 & 41.51 & 0 & 0 & 0 & 0 & 0 & 0 & 25 & 11.90 \\
\hline Maize & 53 & 100 & 52 & 100 & 52 & 100 & 51 & 96.22 & 208 & 99.05 \\
\hline Rice & 2 & 03.77 & 0 & 0 & 0 & 0 & 0 & 0 & 2 & 0.95 \\
\hline Vegetables & 5 & 09.43 & 9 & 17.30 & 7 & 13.46 & 22 & 41.50 & 44 & 20.95 \\
\hline Irrigation & 48 & 90.57 & 42 & 80.76 & 44 & 84.61 & 49 & 92.45 & 183 & 87.14 \\
\hline
\end{tabular}

Source: Estimated from field survey data, 2017.

\section{Perception of the respondents regarding climate change}

The respondents' perception regarding climate change was identified through the two most important climatic variables namely temperature and precipitation. Most of the researchers use these two variables namely; temperature and precipitation. Therefore, questions were asked from the farmers through well a designed interview schedule regarding their perception. Questions were asked about rise in temperature. They were asked to identify whether or not they had noted: (a) Temperature increase (b) Temperature decrease (c) no temperature change (d) increase in precipitation (e) decreases in precipitation (f) no change in precipitation patterns (h) increase in farmers' return from agriculture (i) decrease in farmers' return from agriculture and ( $\mathrm{j}$ ) no change in farmers' return from agriculture due to change in precipitation. Moreover, farmers were addressed to know their view point regarding effect of change in precipitation on their return from agriculture. Among the total targeted respondents, $188 \quad(89.52 \%)$ respondents reported increase in temperature. Similar results were revealed by [23] where majority $(85 \%)$ of the respondents were of the view that there has been a rise in temperature. Similarly, [11] reported that more than half $(52 \%)$ of the farmers perceived increase in temperature. The 11 $(5.24 \%)$ respondents noticed decrease in temperature, while the remaining 11 (5.24\%) respondents realized no change in temperature. Similarly, precipitation also plays a vital role for crop yield everywhere in the world. Majority of the respondents that is $166(79.05 \%)$ observed decrease in rainfall in KP supported by [11, 23, 24] where almost $61 \%$ and $75 \%$ respondents observed a decline in rainfall respectively. Out of the total respondents, $31(14.76 \%)$ respondents noted increase in rainfall, while the remaining 13 (6.19\%) of the respondents observed no change in rainfall. Out of the total selected respondents, majority i.e. $170(80.95 \%)$ of the respondents were of the opinion that return of farmers from agriculture was decreased by change in precipitation, followed by 21 $(10 \%)$ respondents who reported an increase in farmers' return from agriculture due to change in rainfall, while $19(9.05 \%)$ of the respondents observed no effect of precipitation on farmers' return from agriculture (Table 3). 
Table 3. Perception of the respondents regarding climate change

\begin{tabular}{|c|c|c|c|c|c|c|}
\hline \multicolumn{7}{|c|}{ Farmers Perception regarding Temperature } \\
\hline Districts & Peshawar & Abbottabad & U. Dir & Lakki Marwat & Freq. & \%age \\
\hline Increase & 46 & 47 & 49 & 46 & 188 & 89.52 \\
\hline Decrease & 3 & 4 & 1 & 3 & 11 & 5.24 \\
\hline No Change & 4 & 1 & 2 & 4 & 11 & 5.24 \\
\hline \multicolumn{7}{|c|}{ Farmers Perception regarding Precipitation } \\
\hline Increase & 6 & 11 & 9 & 5 & 31 & 14.76 \\
\hline Decrease & 43 & 38 & 41 & 44 & 166 & 79.05 \\
\hline No Change & 4 & 3 & 2 & 4 & 13 & 6.19 \\
\hline \multicolumn{7}{|c|}{} \\
\hline Increase & 5 & 5 & 6 & 5 & 21 & 10.00 \\
\hline Decrease & 39 & 44 & 42 & 45 & 170 & 80.95 \\
\hline No Change & 9 & 3 & 4 & 3 & 19 & 9.05 \\
\hline
\end{tabular}

Source: Estimated from field survey data, 2017.

\section{Estimated logit model for farmers' perception of climate change}

Table 4 presents estimated results for logit model on farmers' perception of climate change. The findings indicate that age, education, farm size, farming experience, extension visits and location in central and southern climatic zones of Khyber Pakhtunkhwa have significant influence on a farmer's perception on climate change. Age has a highly significant negative effect on farmer's perception of climate change. It could be interpreted that younger farmers had more chance to perceive climate change than older ones $(=-0.0392687, p<0.01)$. This may be due to youngers have more access to modern information and are more advanced about farming. Therefore younger farmers have greater sense of realizing changes in the surrounding environment as compared to older farmers. These research findings are similar with that of $[25,26]$. Concerning the educational background of the respondents, study outputs proven that the probability of highly educated farmers to perceive climate change is more than less educated farmers $(=0.0077668, \mathrm{p}<0.05)$. This is due to the reason that higher education enables farmers to be exposed to agricultural information on climate change. Moreover, education enhances the farmers' potential to acquire and interpret information helping in making innovative decisions for performing their field operations. Farm size has no effect on the perception of farmers concerning climate change as it is clear from the results which is non-significant $(p>0.1)$. With regard to farming experience, study results showed that more experienced farmers had higher tendency to recognize climate change than less experienced farmers $\quad(=0.0439332$, $\mathrm{p}<0.01)$.

This is due to the fact that more experienced farmers have more expertise in farming practices and thus be able to recognize any change in climatic patterns over time. Significant effect is also observed for extension visits $(=0.0869686, p<.0 .05)$ of on climate change perception. It means that farmers who are paid extension visits are more updated due to which they perceived change in climate as compared to those farmers who were not paid extension visits as supported by [12, 27]. Farmers in the central and southern climate zone of KP are more likely to perceive climate change (=$0.0619359, \mathrm{p}<0.1)$. Results of this research study are supported by [9] where age, education, farming experience and extension visits/services were found significantly associated with farmers' perception on climate change. 
Table 4. Results of the logistic regression model

\begin{tabular}{|c|c|c|c|c|}
\hline \multirow{2}{*}{ Explanatory variables } & \multicolumn{2}{|c|}{ Regression Model } & \multicolumn{2}{|c|}{ Marginal Effect } \\
\hline & Co-efficient & P-value & Co-efficient & P-value \\
\hline Age & -0.7149414 & 0.0000 & -0.0392687 & $0.0000 * * *$ \\
\hline Education & 0.1414053 & 0.0200 & 0.0077668 & $0.0170^{* *}$ \\
\hline Farm size & -0.0185227 & 0.5370 & -0.0010174 & $0.5360^{\mathrm{NS}}$ \\
\hline Farming experience & 0.799866 & 0.0000 & 0.0439332 & $0.0000 * * *$ \\
\hline Extension visits & 1.583386 & 0.0130 & 0.0869686 & $0.0100 * *$ \\
\hline Southern zone & -1.127631 & 0.0770 & -0.0619359 & $0.0730 *$ \\
\hline Log likelihood & \multicolumn{4}{|c|}{-40.288457} \\
\hline LR chi2(6) & \multicolumn{4}{|c|}{68.68} \\
\hline Prob>chi2 & \multicolumn{4}{|c|}{0.0000} \\
\hline Pseudo R2 & \multicolumn{4}{|c|}{0.4602} \\
\hline
\end{tabular}

Source: Estimated from field survey data, 2017.

Note: $* * *, * *$ and $*$ indicates significance level at $1 \%, 5 \%$ and $10 \%$ probability, respectively

\section{Conclusion and recommendations}

This study examined determinants of farmers' perception about climate change across four climatic zones of Khyber Pakhtunkhwa and investigate farmers' perception of climate change. Response of sampled farmers revealed that majority of them noted a significant increase in annual temperature and decrease in annual precipitation. Due to these changes yield of main crops, such as maize and wheat, and farmers' return from agriculture are affected. This climate variability has signified the role of planning and research in agriculture sector. Thus the need to include programs for maintaining and enhancing the agricultural sustainability in the province should be realized at government level. As in the central and southern climatic zones of Khyber Pakhtunkhwa significant increase in annual temperature and decrease in annual precipitation was reported by majority of sampled farmers, development of high yielding and drought resistant varieties could help reducing potential decrease in yield and returns. The negative effect of temperature or drought could be reduced with supply of more water for irrigation. Education plays significant role in combating hazardous impacts of climate change. Government therefore needs to provide formal as well as informal education to farming communities about the detrimental effects of global warming. Extension visits also important determents of perceiving climate change. Government needs to implement proper monitoring system to assure frequent visits of extension personals in the province.

\section{Authors' contributions}

Conceived main theme of the study: A Khan \& S Ali, Collected Data: A Khan, Analyzed the data: A Khan \& Sanaullah, Contributed materials/ analysis/ tools: SA Shah \& S Ali, Wrote the paper: A Khan, Sanaullah \& SU Khan.

\section{References}

1. Protocol K (1997). United Nations framework convention on climate change. Kyoto Protocol, Kyoto, 19.

2. Molua EL (2002). Climate variability, vulnerability and effectiveness of farm-level adaptation options: the challenges and implications for food security in Southwestern Cameroon. Environ and Devel Economics 7(3): 529-545.

3. McCarthy JJ, Canziani OF, Leary NA, Dokken DJ \& White KS (2001). Climate Change 2001.

4. Trenberth KE (2011). Changes in precipitation with climate change. Climate Res 47(1-2):123-138.

5. Shakoor U, Saboor A, Ali I \& Mohsin A (2011). Impact of climate change on agriculture: empirical evidence from arid region. Pak J of Agric Sci 48(4): 327-333.

6. Hanif U, Syed SH, Ahmad R, Malik KA \& Nasir M (2010). Economic impact of climate change on the agricultural sector of Punjab. The Pak Dev Rev 771-798.

7. GoP (2018). Pakistan Economic Survey, 2017-18. Ministry of Finance, Economic Advisory Wing, Finance Division, Islamabad, Pakistan. 
8. GoP (2010). Task Force on Climate Change, Planning Commission of Pakistan.

9. Ndambiri HK, Ritho C, Mbogoh SG, Nyangweso P. M, Ng'ang'a S. I, Muiruri E. J \& Omboto PI (2012). Analysis of farmers' perceptions of the effects of climate change in Kenya: the case of Kyuso district, No. 304-2016-4806, pp 309.

10. Apata TG, Samuel KD \& Adeola AO (2009). Analysis of Climate Change Perception and Adaptation among Arable Food Crop Farmers in South Western Nigeria (No. 1005-2016-79140).

11. Asrat P \& Simane B (2018). Farmers' perception of climate change and adaptation strategies in the Dabus watershed, NorthWest Ethiopia. Ecological Processes 7(1): 7.

12. Deressa TT, Hassan RM \& Ringler C (2011). Perception of and adaptation to climate change by farmers in the Nile basin of Ethiopia. The J of Agricu Sci 149(1): 2331.

13. Waibel H, Pahlisch TH \& Völker M (2018). Farmers' perceptions of and adaptations to climate change in Southeast Asia: the case study from Thailand and Vietnam. In Climate Smart Agric. Springer, Cham, pp 137-160.

14. Elum ZA, Modise DM \& Marr A (2017). Farmer's perception of climate change and responsive strategies in three selected provinces of South Africa. Climate Risk Manag 16: 246-257.

15. Hassan RM \& Nhemachena C (2008). Determinants of African farmers' strategies for adapting to climate change: Multinomial choice analysis. African $J$ of Agric and Res Econ 2(311-2016-5521): 83.

16. Tesfahunegn GB, Mekonen $\mathrm{K} \&$ Tekle A (2016). Farmers' perception on causes, indicators and determinants of climate change in northern Ethiopia: Implication for developing adaptation strategies. Appl Geogr 73: 1-12.

17. Gbetibouo GA, Ringler C.\& Hassan R (2010). Vulnerability of the South African farming sector to climate change and variability: an indicator approach. In Nat Res Forum 34(3): 175-187).

18. Mendelsohn R, Nordhaus WD \& Shaw D (1994). The impact of global warming on agriculture: a Ricardian analysis. The American Econ Rev 753-771.

19. Cochran WG (1977). Sampling techniques3.ed. John Wiley \& Sons. New York.

20. Daniel WW (1999). Biostatistics: A Foundation for analysis in the health sciences, 7thedR Wiley. New York.

21. Gujarati DN (2009). Basic econometrics. Tata McGraw-Hill Education.

22. Feder G, Just RE \& Zilberman D (1985). Adoption of agricultural innovations in developing countries: A survey. Economic Dev and Cult Change 33(2): 255-298.

23. Amdu B, Ayehu A \& Deressa A (2013). Farmers' perception and adaptive capacity to climate change and variability in the upper catchment of Blue Nile, Ethiopia.

24. Lemma WA (2016). Analysis of smallholder farmers' perceptions of climate change and adaptation strategies to climate change: the case of Western Amhara Region, Ethiopia. http://hdl.handle.net/10500/22158

25. Ishaya S \& Abaje IB (2008). Indigenous people's perception on climate change and adaptation strategies in Jema'a local government area of Kaduna State, Nigeria. $J$ of Geogr and Reg Planning 1(8): 138.

26. Maddison D (2007). The perception of and adaptation to climate change in Africa. The World Bank.

27. Kurukulasuriya P, Mendelsohn R, Hassan R, Benhin J, Deressa T, Diop M \& Mahamadou A (2006). Will African agriculture survive climate change?. The World Bank Econ Rev 20(3): 367-388. 